\title{
EFFORTS TO INCREASE ACTIVITY AND RESULTS OF MATH STUDENTS LEARNING THROUGH APLICATION MODEL MAKE A MATCH TYPE COOPERATIVE LEARNING PRIMARY CLASS VI SD NEGERI 168432 TEBING TINGGI
}

\author{
Nurainun Harahap \\ Surel: ibunurainunharahap@gmail.com
}

\begin{abstract}
The research aims to find out student learning activities, and improve student learning outcomes by applying cooperative learning model Type Make A Match on classroom material of class VI circle of 38 students. The object of this research is the application of Cooperative Learning Model Type Make A Match (looking for partner). This study is a classroom action research. To obtain data in this research used observation sheet and test result of student learning in the form of objective test as much as 5 problem esay. In this study used 3 cycles, consisting of 4 stages, namely planning, implementation, observation, and reflection. Activity and result of learning mathematics before applied model of Cooperative Learning Type Make A Match.
\end{abstract}

Keywords: Activity, Co-operative Learning, Make A Match

\begin{abstract}
ABSTRAK
Penelitian bertujuan untuk mengetahui aktivitas belajar siswa, dan peningkatan hasil belajar siswa dengan menerapkan model pembelajaran Kooperatif Tipe Make A Match pada materi luas lingkaran kelas VI sebanyak 38 siswa. Objek dalam penelitian ini adalah penerapan model pembelajaran Kooperatif Tipe Make A Match (mencari pasangan). Penelitian ini adalah penelitian tindakan kelas. Untuk memperoleh data dalam penelitian ini digunakan lembar observasi dan tes hasil belajar siswa berupa tes objektif sebanyak 5 soal esay. Dalam penelitian ini digunakan 3 siklus, yang terdiri dari 4 tahap, yaitu perencanaan, pelaksanaan, observasi, dan refleksi. Aktivitas dan hasil belajar matematika sebelum diterapkan model pembelajaran Kooperatif Tipe Make A Match.
\end{abstract}

Kata Kunci : Aktifitas, Model Kooperatif, Make A Match

\section{PENDAHULUAN}

Didalam dunia pendidikan, matematika memegang peranan penting yang cukup penting. Banyak yang telah disumbangkan matematika untuk kemajuan peradaban manusia.
Selain itu tanpa bantuan matematika, maka semua ilmu pengetahuan Cocroft (dalam Abdurrahman, 2009: 253) bahwa: Matematika perlu diajarkan kepada siswa karena (a) selalu digunakan dalam segala segi

Guru SD Negeri 168432 Tebing Tinggi 
kehidupan, (b) semua bidang studi memerlukan keterampilan matematika yang sesuai (c) merupakan sarana komunikasi yang kuat, singkat dan jelas (d) dapat digunakan untuk menyajikan informasi dalam berbagai cara (e) meningkatkan kemampuan berpikir logis,ketelitian dan kesadaran kekurangan dan (f) memberikan kepuasan terhadap usaha memecahkan masalah yang menantang.

Salah satu faktor yang mempunyai andil yang sangat penting dalam menentukan keberhasilan belajar matematika adalah pemilihan model pembelajaran dalam menyajikan pelajaran sangat berpengaruh terhadap aktivitas dan hasil belajar siswa. Penggunaan model pembelajaran yang tepat akan mengatasi kejenuhan siswa dalam menerima pelajaran matematika. Dari hasil wawancara dari salah satu guru matematika di kelas VI SD Negeri 168432 Kota Tebing Tinggi Tahun Ajaran 2016/2017 mengatakan bahwa: Aktivitas siswa dalam mengikuti materi matematika masi kurang, kebanyakan siswa hanya memperhatikan saja tanpa mau bertanya. Siswa cenderung hanya menyalin materi-materi yang dijelaskan oleh guru. Pada halnya menyalin materi-materi dijelaskan oleh guru. Pada halnya siswa masi kesulitan memahami materi. Diantaranya yaitu masih kesulitan dalam menyelesaikan soal-soal yang terkait dengan masalah kehidupan sehari-hari. Mengakibatkan hasil belajar matematika yang dicapai siswa masih rendah.

Fakta tersebut ditunjukan oleh nilai hasil belajar matematika siswa adalah 60,00 dalam hal ini berarti masih di bawah kriteria ketuntasan minimal (KKM) seperti yang ditetapkan oleh sekolah yang bersangkutan yaitu 70 .

Pembelajaran terpusat pada guru sampai saat ini masih menemukan beberapa kelemahan. Kelemahan tersebut dapat dilihat pada saat berlangsungnya proses pembelajaran dikelas, interaksi siswa dengan guru atau siswa dengan siswa jarang terjadi. Siswa kurang terampil dalam menjawab pertanyaan atau bertanya tentang konsep yang diajarkan. Siswa kurang bisa bekerja dalam kelompok diskusi dan memecahkan masalah yang diberikan. Siswa cenderung belajar sendirisendiri. Pembelajaran yang disampaikan dengan ceramah membuaat siswa bosan, tidak bersemangat dikelas, kurang aktif dalam bertanya dan menjawab pertanyaan dan tidak berantusias saat berdiskusi kelompok dengan temannya. Dengan begitu siswa tidak dapat memahami konsep yang dipelajari dengan baik. Selain itu para guru terjebak dengan target kurikulum, sehingga kurang memperhatikan apakah siswa mengerti atau tidak materi yang diterimanya. 
Agar siswa dapat memahami konsep matematika dengan baik maka perlu dikembangkan suatu cara atau metode pengajaran matematika guna membantu siswa dalam memahami konsep dan menentukan hubungan yang bermakna dalam menyelesaikan soal. Salah satu model pembelajaran yang memungkinkan agar siswa dapat memahami konsep matematika dengan baik yaitu model pembelajaran Kooperatif Tipe Make A Match karena keunggulan model ini adalah model tersebut dapat digunakan untuk semua mata pelajaran dan untuk semua tingkatan usia anak didik, dan dalam model ini anak didik mencari pasangan sambil belajar mengenai suatu konsep atau topik dalam suasana yang menyenangkan.

Berdasarkan uraian diatas maka penulis tertarik untuk mengadakan penelitian dengan judul "Upaya Meningkatkan Aktivitas Dan Hasil Belajar Matematika Siswa Melalui Penerapan Model Pembelajaran Kooperatif Tipe Make A Match Di Kelas VI SD Negeri 168432 Kota Tebing Tinggi Tahun Ajaran 2016/2017".

Berdasarkan latar belakang masalah yang telah diuraikan diatas, maka dapat diidentifikasi masalah yang relavan dengan penelitian antara lain :

1. Siswa menganggap matematika sebagai mata pelajaran yang sulit.
2. Kurangnya Aktivitas belajar siswa.

3. Rendahnya Hasil belajar matematika siswa.

4. Kegiatan pembelajaran yang masih didominasi oleh guru.

Berdasarkan batasan masalah yang telah dikemukan diatas, maka rumusan masalah dalam penelitian ini adalah :

1. Apakah melalui penerapan model pembelajaran kooperatif tipe make a match dapat meningkatkan aktivitas siswa pada materi luas lingkaran dikelas VI SD Negeri 168432 Kota Tebing Tinggi Tahun Ajaran 2016/2017.

2. Apakah melalui penerapan model pembelajaran kooperatif tipe make a match dapat meningkatkan hasil belajar siswa pada materi luas lingkaran dikelas VI SD Negeri 168432 Kota Tebing Tinggi Tahun Ajaran 2016/2017.

\section{METODE PENELITIAN}

Desain penelitian ini merupakan penelitian tindakan kelas (Classroom Action Research) yaitu penelitian yang dilakukan dengan memperbaiki mutu praktik pembelajaran dikelas. Penelitian tindakan kelas bercirikan perbaikan secara terus-menerus, pelaksanaan tindakan dalam penelitian ini terdiri dari atas permasalahan, alternatif pemecahan (perencanaan tindakan), 
pelaksanaan tindakan, pengamatan, analisis data, dan refleksi. Pelaksanaan tindakan ini secara berdaur ulang. Apabila pada tindakan/siklus satu telah mencapai tujuan yang diinginkan maka langsung dapat ditarik kesimpulan, tetapi jika ada perbaikan-perbaikan, atau model yang digunakan tidak berhasil masi dilanjutkan dengan tindakan selanjutnya. Dalam penelitian ini direncanakan hanya sampai 3 siklus saja, dan tiap siklus terdiri dari 2 kali pertemuan.

\section{Siklus I}

Pada penelitian ini, masalah yang diduga penulis adalah hasil belajar siswa yang masih rendah belum mencapai nilai ketuntasan hasil belajar dan kurangnya aktifitas siswa pada saat pembelajaran berlangsung. Faktor yang menjadi penyebabnya adalah metode pengajaran yang digunakan masih monoton dan kurang bervariasi. Guru juga masih kurang dalam melibatkan siswa dalam pembelajaran, sehingga siswa kurang aktif. Berdasarkan permasalahan tersebut, disusunlah suatu perencanaan untuk mengatasinya.

\section{Perencanaan}

Pada tahap perencanaan tindakan ini, hal-hal yang dilakukan adalah:

a. Menyusun Rencana Pelaksanaan Pembelajaran (RPP) dengan menggunakan model pembelajaran kooperatif tipe make a match. b. Membuat alat bantu untuk pelaksanaan pembelajaran berupa Lembar Aktivitas Siswa (LAS), dan buku untuk peneliti yang berisi skenario pembelajaran.

c. Mempersiapkan instrumen penelitian, yaitu: (a) tes untuk mengukur hasil belajar siswa, (2) lembar observasi untuk mengamati kegiatan (proses) belajar mengajar

d. Lembar observasi mengamati kegitan aktivitas siswa.

\section{Pelaksanaan}

Setelah perencanaan tindakan I disusun dengan matang, maka tahap selanjutnya adalah pelaksanaan tindakan I. pada tahap ini, pemberian tindakan dilakukan dengan melakukan kegiatan belajar mengajar. Kegiatan mengajar yang dilakukan merupakan pengembangan dari pelaksanaan dari prosedur pengajaran (rencana pembelajaran) yang telah disusun. Peneliti berperan sebagai pengajar dikelas dengan menerapkan model pembelajaran kooperatif tipe make a match. Sedangkan guru di kelas sebagai observer untuk melihat kegiatan proses belajar mengajar sekaligus memberikan masukan tentang pembelajaran yang sedang berlangsung. Pada akhir pembelajaran, diberikan tes hasil belajar I yang dikerjakan secara individual untuk melihat apakah ada peningkatan hasil belajar siswa yang dicapai dalam tindakan tersebut. 


\section{Observasi}

Observasi dilaksanakan pada saat berlangsungnya proses belajar mengajar dengan menggunakan pedoman observasi yang telah dipersiapkan untuk mengetahui aktivitas siswa dalam proses pembelajaran di kelas serta kendalakendala yang dihadapi, baik yang di alami oleh peserta didik maupun oleh guru itu sendiri . Dalam pelaksanaan observasi ini, guru bidang study matematika kelas VI SD Negeri 168432 mengobservasi peneliti yang bertindak sebagai guru dengan tujuan apakah kondisi belajar sudah terlaksana sesuai dengan rencana pembelajaran.

\section{Refleksi}

1. Guru dan peneliti menganalisis dan mendiskusikan hasil pengamatan. Selanjutnya membuat suatu refleksi mana yang perlu dipertahankan dan mana yang perlu diperbaiki untuk siklus ke-2 nantinya.

2. Merekapitulasi tessiklus I sebagai pertimbangan perencanaan pembelajaran berikutnya.

3. Kemudian siswa yang kurang aktif pada siklus I diupayakan jalan keluarnya supaya aktif.

\section{Siklus II dan III}

Pada prinsipnya semua kegiatan siklus II mirip dengan siklus
I. Siklus II merupakan perbaikan pada siklus I, terutama didasarkan atas hasil refleksi pada siklus I. Setelah dilaksanakan siklus II dan hasil perbaikan yang diharapkan belum tercapai terhadap aktivitas dan hasil belajar yang telah ditetapkan peneliti, maka masih perlu dilanjutkan tindakan pada siklus III. Pada siklus III ini diadakan perencanaan kembali dengan mengacu pada hasil refleksi pada siklus II, akan tetapi, juga harus mengadakan perbaikan-perbaikan pada bagian-bagian yang dianggap kurang pada siklus II tersebut

Subjek penelitian ini adalah seluruh siswa kelas VI SD Negeri 168432 Kota Tebing Tinggi Tahun Ajaran 2016/2017 yang terdiri dari satu kelas yang berjumlah 38 siswa.

Objek penelitian ini adalah pembelajaran matematika dengan penerapan model pembelajaran kooperatif tipe make a match dalam meningkatkan aktivitas dan hasil belajar matematika siswa kelas VI SD Negeri 168432 Tahun Ajaran 2016-2017.

Penelitian tindakan kelas ini dilaksanakan di SD Negeri 168432 yang beralamat di jalan rumah sakit umum kelurahan pasar baru kecamatan Tebing Tinggi Kota.

Waktu penelitian dilakukan pada semester Ganjil Tahun Ajaran 2016/2017.

Lembar observasi siswa adalah alat untuk mengamati dan menilai keaktifan siswa saat proses 
pembelajaran berlangsung. Lembar observasi ini disiapkan oleh peneliti dan pengisiannya berbentuk checklist $(\sqrt{ })$ dengan alternatif jawaban 1 dan 0 untuk menandai terjadi atau tidaknya kegiatan pembelajaran yang telah direncanakan sesuai dengan karakteristik model pembelajaran Make a Match. Untuk memberikan keterangan mengenai kejadian esensial yang diamati, lembar observasi ini memuat kolom deskripsi. Lembar observasi digunakan oleh peneliti sebagai pedoman dalam mengamati secara langsung selama proses pembelajaran.

Tabel I. Lembar Observasi Siswa

\begin{tabular}{|c|c|c|c|}
\hline No. & $\begin{array}{l}\text { Aspek yang } \\
\text { diamati }\end{array}$ & Kriteria Penilaian & Skor Perolehan \\
\hline \multirow[t]{2}{*}{1} & \multirow{2}{*}{$\begin{array}{l}\text { Mengemukaka } \\
\mathrm{n} \text { ide dan } \\
\text { pendapat }\end{array}$} & Tidak mampu mengemukan pendapat & 0 \\
\hline & & Mampu mengemukakan pendapat & 1 \\
\hline \multirow[t]{2}{*}{2} & \multirow[t]{2}{*}{ Bertanya } & $\begin{array}{l}\text { Tidak mengajukan pertanyaan dan } \\
\text { hanya mengobrol dengan } \\
\text { pasangannya }\end{array}$ & 0 \\
\hline & & Mengajukan pertanyaaan & 1 \\
\hline \multirow[t]{2}{*}{3} & \multirow[t]{2}{*}{ Mendengar } & $\begin{array}{l}\text { Siswa asyik becanda dengan } \\
\text { temannya }\end{array}$ & 0 \\
\hline & & Siswa mendengar temannya & 1 \\
\hline \multirow[t]{2}{*}{4} & \multirow[t]{2}{*}{ Bekerjasama } & $\begin{array}{l}\text { Tidak bekerjasama dengan } \\
\text { kelompoknya }\end{array}$ & 0 \\
\hline & & Bekerjasama dengan kelompoknya & 1 \\
\hline \multirow[t]{2}{*}{5} & \multirow{2}{*}{$\begin{array}{l}\text { Mengerjakan } \\
\text { LKS }\end{array}$} & Tidak mengerjakan soal & 0 \\
\hline & & $\begin{array}{l}\text { Mengerjakan soal dengan tekun dan } \\
\text { mandiri }\end{array}$ & 1 \\
\hline
\end{tabular}

\section{Data Kuantitatif}

1. Tes

Tes yang diberikan kepada siswa tes awal dan tes hasil belajar. Tes awal dilaksanakan sebelum pembelajaran dilakukan. Pemberian tes awal ini bertujuan untuk mengetahui tingkat kemampuan awal siswa dan juga untuk mengetahui kesulitan-kesulitan siswa dalam menyelesaikan soal yang berkaitan dengan materi persyarat untuk mengikuti materi bilangan bulat. Sedangkan tes hasil belajar diberikan setelah pembelajaran melalui model pembelajaran tipe make a match yang dilakukan oleh peneliti. Tes sebagai alat ukur untuk penilaian hasil belajar dilakukan sebanyak 3 kali, yaitu tes hasil belajar I setelah diberikan tindakan I dan tes hasil belajar II dan tes hasil belajar III (setelah pemberian 
siklus III). Dalam arti apakah nilai tes awal tersebut menjadi lebih baik atau tidak dibandingkan dengan nilai tes hasil belajar sebelum tes dilakukan Ada beberapa hal yang perlu diperhatikan oleh peneliti sebelum menyusun naskah tes, yaitu :

a. Menentukan ruang lingkup pertanyaan.

b. Menentukan apa yang diukur meliputi aspek kognitifnya, yaitu pengetahuan (C1), pemahaman (C2), dan penerapan (C3).

c. Menyusun kisi-kisi tes.

d. Dalam kisi-kisi tampak ruang lingkup materi yang diujikan, bentuk soal, dan jumlah soal.

e. Menyusun soal berdasarkan kisi-kisi yang telah dibuat.

f. Membuat penyelesaian soal.

Dalam penyusunan tes, sebelum tes dibuat terlebih dahulu dibuat kisi-kisi sebagai rambu-rambu penjabaran konsep menjadi butir item. Tes yang telah disusun, kemudian diuji cobakan pada populasi yang tidak dijadikan sampel penelitian. Tujuan uji coba adalah untuk melihat apakah instrumen yang telah disusun benar-benar valid atau benar-benar reliabel atau tidak.

\section{Uji Validitas}

Tujuan memeriksa validitas instrumen adalah untuk melihat apakah instrument tersebut mampu mengukur apa yang ingin diukur sehingga instrument tersebut dapat mengungkapkan data yang ingin diukur. Untuk menentukan validitas suatu tes, maka peneliti menggunakan rumus Korelasi Product Momen (dalam Arikunto, 2012:87), sebagai berikut :

$$
\mathrm{r}_{\mathrm{xy}}=\frac{n \cdot \sum \boldsymbol{x} \boldsymbol{y}-\left(\sum \boldsymbol{x}\right)\left(\sum \boldsymbol{y}\right)}{\left.\sqrt{n \cdot \sum_{x} 2}-\left(\sum_{x}\right) 2\right)\left(\sum_{y} 2-\left(\sum_{y} 2\right)\right.}
$$

Keterangan :

$\mathrm{r}_{\mathrm{xy}}=$ Validitas soal

$\mathrm{n}=$ Jumlah siswa

$\Sigma \mathrm{x}=$ Skor siswa pada tiap butir soal

$\Sigma \mathrm{y}=$ Nilai / Skor total

$\sum x y=\operatorname{Jumlah}(\mathrm{x})(\mathrm{y})$

Angka hasil perhitungan $r_{x y}$ kemudian dibandingkan dengan korelasi product moment pada tabel $\mathrm{r}_{\mathrm{xy}}$ dengan taraf signifikansi $5 \%$. Butir soal dinyatakan valid apabila $r_{x y}$ $\geq r_{\text {tabel. }}$

Tabel II. Interpretasi Kriteria Validitas

\begin{tabular}{|c|c|}
\hline Nilai $\mathrm{r}_{\mathrm{xy}}$ & Interpretasi \\
\hline $0,80-1,00$ & Sangat Tinggi \\
\hline $0,60-0,79$ & Tinggi \\
\hline $0,40-0,59$ & Cukup \\
\hline $0,20-0,39$ & Rendah \\
\hline $0,00-0,19$ & Sangat Rendah \\
\hline
\end{tabular}

\section{HASIL DAN PEMBAHASAN}

Untuk mengetahui permasalahan dilakukan pemberian tes awal kepada subjek penelitian. Subjek dalam penelitian ini adalah kelas VI SD Negeri 168432 yang masing berjumlah 38 orang. Tes awal ini selain bertujuan untuk mengetahui kemampuan awal siswa dalam menyelesaikan soal-soal yang berkaitan dengan operasi bilangan bulat. Hasil tes awal menunjukan masi banyak siswa yang tidak bisa 
menyelesaikan soal operasi bilangan bulat.

Adapun kemampuan siswa diberikan tindakan dilihat dari hasil tes awal siswa dikelas VI belum dapat dikatakan tuntas karena presentase ketuntasan klasikal belum mencapai 85\%. Dari tabel nilai tes diperoleh nilai terendah 20 dan nilai tertinggi 75. Dari 38 siswa, 9 orang siswa (24\%) yang mencapai tingkat ketuntasan belajar. Sedangkan 29 orang siswa (76\%). Ketuntasan belajar secara klasikal pada pra siklus belum terpenuhi karena di dalam kelas hanya terdapat $24 \%$ siswa yang berhasil mencapai nilai $\geq 70$ dapat dilihat pada (lampiran $\mathrm{O}$ ).

Ketuntasan belajar matematika siswa pada pra siklus dapat jelas terlihat pada diagram dibawah ini.

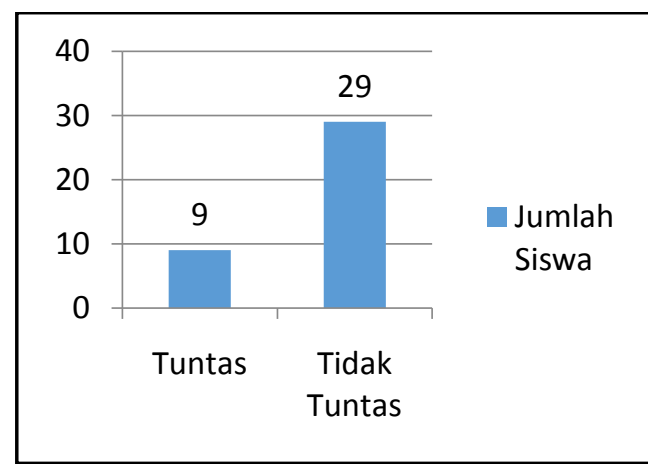

\section{Grafik I : Ketuntasan Belajar Siswa Pra Siklus}

Berdasarkan data penelitian hasil belajar matematika siswa pada pra siklus menunjukan masih terdapat siswa yang belum mengetahui pengetahuan awal dari materi, terletak pada kategori belum mencapai ketuntasan belajar sebesar $85 \%$.

Siklus I

Setelah melaksanakan dan melihat hasil pretes sebelumnya maka sekarang peneliti, tahap selanjutnya adalah pelaksanaan tindakan I. pada tahap ini peneliti bertindak sebagai guru yang menerapkan model Pembelajaran kooperatif tipe make a match sesuai dengan yang disusun. Peneliti dapat melaksanakan siklus I yang dimulai tanggal 19 juli 2016.

1. Pengamatan I

a. Kegiatan pembelajaran

Pertemuan I

Pengamatan

proses

pembelajaran pada pertemuan pertama mulanya kondusif, namun pada saat pelaksanaan make a match siswa kurang memahami dan siswa kurang memahami dan siswa keliru dalam melaksanakannya.

Pertemuan II

Proses pembelajaran pada pertemuan II kondisi kelas lebih kondusif dibandingkan dengan pertemuan I. Hal ini disebabkan karena siswa sudah memahami tentang model pembelajaran yang digunakan dalam pembelajaran.

Untuk pengamatan aktivitas siswa dilaksanakan pada pertemuan II. Peneliti dibantu oleh guru pelajaran matematika dalam melakukan penilaian aktivitas. Dengan menggunakan pedoman 
penskoran, guru menilai aktivitas siswa selama kegiatan pembelajaran. Rekapitulasi hasil penilaian dapat dilihat dari tabel dibawah ini.

\section{Tabel III. Ketuntasan Tes Hasil Belajar Siklus I}

\begin{tabular}{|c|c|c|}
\hline No & Kriteria & $\begin{array}{c}\text { Jumlah } \\
\text { Siswa }\end{array}$ \\
\hline 1 & Tuntas & 16 \\
\hline 2 & Tidak Tuntas & 22 \\
\hline \multicolumn{2}{|c|}{ Ketuntasan Klasikal } & $58 \%$ \\
\hline
\end{tabular}

Dari hasil nilai di atas dapat kita ketahui bahwa siswa yang tuntas hanya berjumlah 16 siswa, sedangkan 22 siswa lainnya masih dalam kategori tidak tuntas. Hal ini mengartikan bahwa ketuntasan klasikal yang diperoleh hanya $42 \%$. Berikut grafik ketuntasan siswa

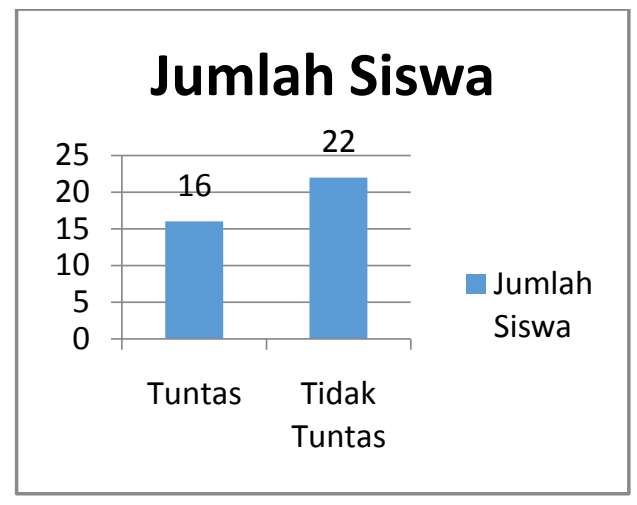

\section{Grafik II. Ketuntasan Tes Hasil Belajar Siklus I}

Dari hasil tes siklus I dan pengamatan peneliti, faktor penyebab kurang tercapainya hasil seperti yang diharap kan antara lain adalah :
1. Ada beberapa siswa yang memberanikan diri untuk bertanya kepada peneliti maksud dari kartu yang ia pegang.

2. Siswa dianjurkan untuk memikirkan sendiri terlebih dahulu permasalahan yang adap ada soal.

3. Masih ada siswa yang berbincangbincang di kelas ketika peneliti sedang memberikan materi.

4. Peneliti kurang aktif memberikan pengarahan, dan kurang banyak memberikan contoh dan kondusifnya suasana kelas.

5. Hanya beberapa pasangan kelompok untuk memaparkan hasil kartu mereka ke depan kelas sekitar 5 pasangan kelompok dipanggil secara berurutan.

6. Pasangan siswa masih kurang berminat untuk menanggapi hasil diskusi kelompok penyaji sehingga guru harus menyebutkan nama pasangan siswa untuk memintai tanggapan ada 5 siswa.

Setelah melaksanakan dan melihat hasil sebelumnya maka sekarang peneliti akan melanjutkan siklus II yang dimulai tanggal 27 juli 2016.

Selama proses pembelajaran berlangsung, segala jenis aktivitas belajar siswa diobservasi oleh seorang observer yaitu mahasiswa dan dibantu oleh guru pelajaran pendidikan matematika. Observasi ini bertujuan untuk mengetahui bagaimana aktivitas siswa selama proses 
pembelajaran dengan menggunakan model pembelajaran siklus, Rekapitulasi hasil penilaian dapat dari table di bawah ini:

\section{Tabel IV. Ketuntasan Tes Hasil Hasil Belajar Siklus II}

\begin{tabular}{|c|c|c|}
\hline NO & Kriteria & Jumlah Siswa \\
\hline 1 & Tuntas & 21 \\
\hline 2 & TidakTuntas & 17 \\
\hline
\end{tabular}

Dari tabel di atas dapat kita ketahui siswa yang tuntas berjumlah 21 siswa, sedangkan 17 siswa lainnya masih dalam kategori tidak tuntas. Sehingga ketuntasan klasikal hanya mencapai $55 \%$. Secara ringkas dapat dilihat dari grafik berikut:

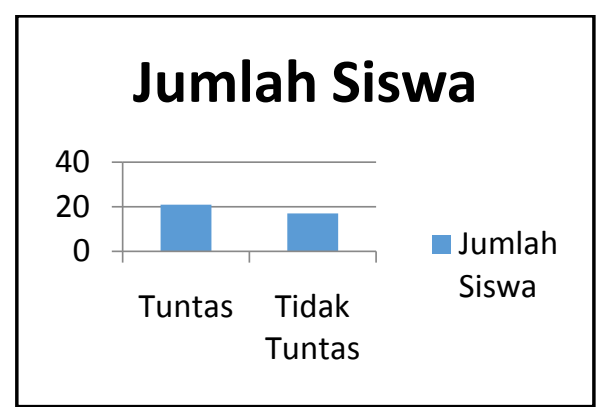

\section{Grafik III Ketuntasan Tes Hasil Belajar Siklus II}

Dari hasil evaluasi siklus II dan pengamatan peneliti, faktor penyebab kurang tercapainya hasil seperti yang diharap kan antara lain adalah :

1) Masih ada siswa yang belum memahami sifat-sifat perjumlahan dan pengurangan pada bilangan bulat.
2) Masih ada siswa yang belum maksimal menggunakan model pembelajaran yang dipergunakan sehingga siswa kurang dapat mendapat informasi tentang kegiatan pembelajaran.

3) Pada saat mengerjakan soal latihan, masih ada siswa yang kurang termotivasi untuk menyelesaikan soal.

4) Masih kurangnya tanggung jawab dalam melaksanakan tugas dan partisipasi aktif siswa dalam proses kerja kelompok.

5) Masih ada siswa yang pasif saat proses kegiatan pembelajaran berlangsung.

Setelah melaksanakan dan melihat hasil tes sebelumnya maka sekarang peneliti akan melanjutkan siklus III yang dimulai tanggal 3 Agustus 2016.

\section{Tabel V. Ketuntasan Tes Hasil Belajar Siklus III}

\begin{tabular}{|c|c|c|}
\hline NO & Kriteria & $\begin{array}{c}\text { Jumlah } \\
\text { Siswa }\end{array}$ \\
\hline 1 & Tuntas & 33 \\
\hline 2 & Tidak Tuntas & 5 \\
\hline
\end{tabular}

Dari hasil nilai di atas dapat kita ketahui bahwa rata-rata skor siswa adalah 74,22 dimana siswa yang tuntas berjumlah 33 siswa, sedangkan 5 siswa lainnya masih dalam kategori tidak tuntas. Dan skor terendah yang didapatkan siswa adalah 50. Secara ringkas dapat dilihat dari grafik berikut. 


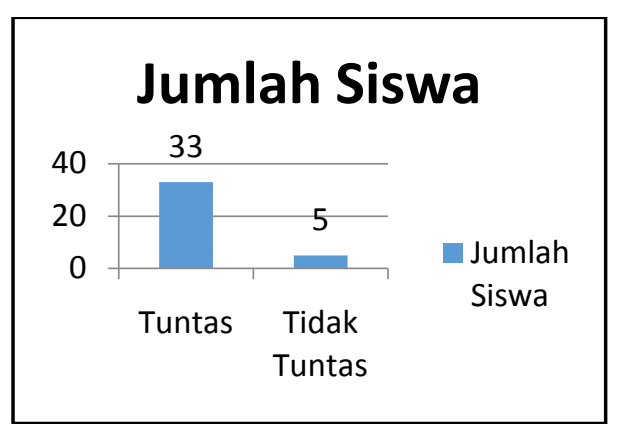

\section{Grafik IV. Ketuntasan Tes Hasil Belajar Siklus III}

Pada siklus I pelaksanaan model make a match belum dapat berlangsung secara optimal. Hal ini disebabkan model ini merupakan metode baru dalam proses pembelajaran. Siswa masih kaku dan belum terbiasa dengan model pembelajaran yang digunakan oleh guru.

Penilaian aktivitas dari tiaptiap aspek, aktivitas siswa dengan menggunakan model pembelajaran make a match menunjukkan bahwa mengemukakan ide dan pendapat jumlah siswa adalah 22 siswa (57\%) bertanya sebesar berjumlah 15 siswa (39\%) mendengaradalah 18 siswa (47\%), kerja sama 26 (68\%), dan mengerjakan LKS 19 siswa (50\%) Pada Siklus II, pada aspek pertama yaitu Jumlah siswa mengemukakan ide adalah 27 Siswa (71\%). Aspek bertanya 24 siswa (63\%). Mendengar 26 siswa (68\%). Kerja sama 25 siswa (65\%), dan mengerjakan LKS 26 siswa (68\%) Pada siklus III juga mengalami perubahan jika dibandingkan dengan aktivitas di siklus ke-2. Pada Aspek pertama yaitu mengemukan ide danpendapat33 siswa $(86 \%)$, bertanya 31 siswa (81\%). Mendengar 32 siswa (84\%). Kerjasama31 siswa (81\%), danmengerjakan LKS 32 siswa (84\%) Sedangkan untuk pengamatan berdasarkan tingkat perbandingan aktivitas kelas dapat kita lihat pada grafik berikut:

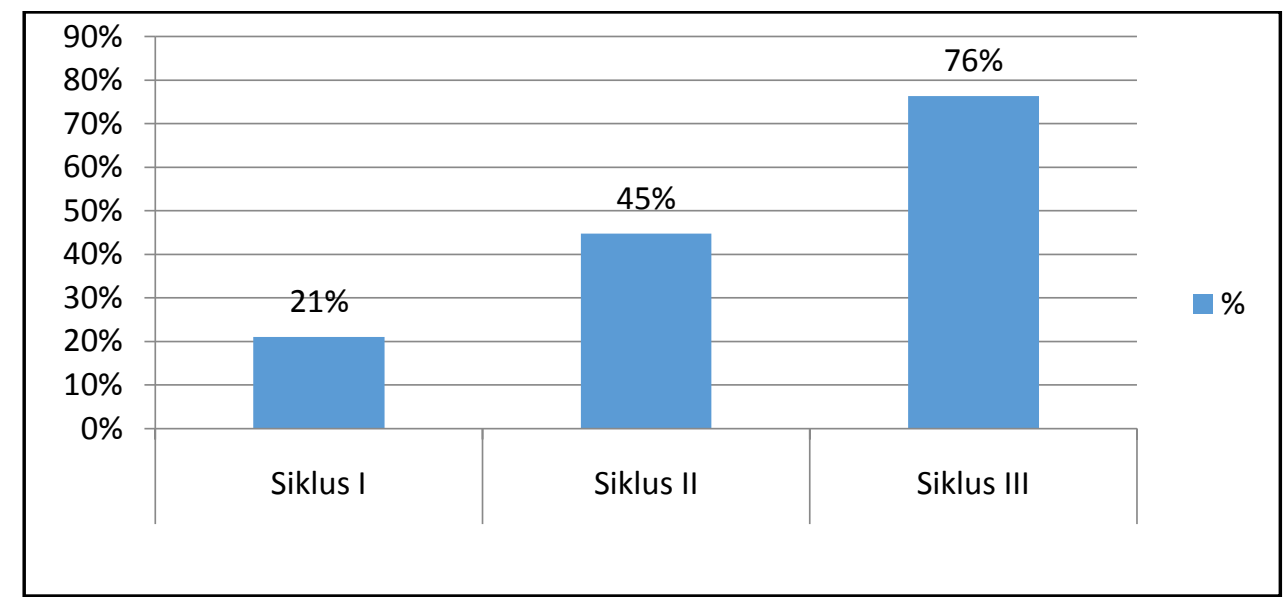

Gambar 3 Persentase Aktivitas Kelas 
Pada siklus I persentase aktivitas kelas masih cukup rendah, yaitu hanya $21 \%$ dari jumlah siswa

Perbandingan jumlah ketuntasan siswa pada tes hasil belajar di setiap siklus dapat kita lihat pada tabel di bawah ini.

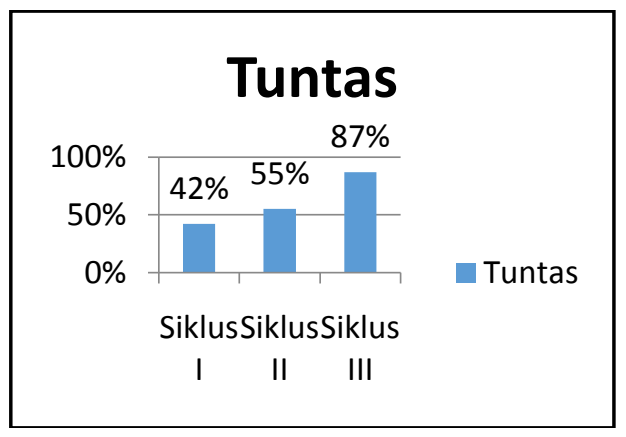

\section{Gambar 4 Perbandingan Nilai Klasikal Tes Hasil Belajar}

Pada Siklus I, kemampuan siswa dalam materi yang diberikan masih sangat rendah. Nilai klasikal yang diperoleh hanya $42 \%$. Setelah dilakukan refleksi dan perbaikan pada pelaksanaan di siklus II, nilai klasikal meningkat menjadi 55\%. Namun hal tersebut belum mencukupi persentase klasikal yang dibutuhkan yakni $87 \%$. Setelah melakukan refleksi dan perbaikan lagi, persentase aktivitas pun menjadi $88 \%$.

\section{SIMPULAN}

Berdasarkan uraian dari pembahasan pada penelitian ini, maka peneliti mengambil kesimpulan sebagai berikut:

$$
\begin{aligned}
& \text { 1. Meningkatnya } \\
& \text { belajar siswa kelas VI SD }
\end{aligned}
$$

keseluruhan. Pada siklus II meningkat menjadi $45 \%$. Dan pada siklus III semakin meningkat menjadi $76 \%$.

Negeri 168432 Kota Tebing Tinggi pada materi Luas Lingkaran pembelajaran kooperatif tipe make a match pada siklus I, siklus II dan siklus III. Rata-rata Aktivitas Kelas pada siklus I sebesar $21 \%$ meningkat menjadi $45 \%$ pada siklus II dan meningkat menjadi $76 \%$ pada siklus III.

2. Meningkatnya hasil belajar siswa kelas VI SD Negeri 168432 Kota Tebing Tinggi Tahun Ajaran 2016/2017 pada materi luas lingkaran. model pembelajaran kooperatif tipe make a match pada siklus I, siklus II dan siklus III. Terjadi peningkatan pada tes hasil belajar siswa siklus I dengan ketuntasan yang dicapai pada siklus I sebesar 42\%, pada siklus II sebesar 55\%, dan $87 \%$ pada siklus III.

Sebagaimana hasil penelitian yang telah dilakukan bahwa penerapan model pembelajaran kooperatif tipe make a match dapat meningkatkan aktivitas dan hasil belajar siswa, dengan ini peneliti memberikan saran :

1. Bagi sekolah, sebaiknya model pembelajaran koopertif tipe mencari pasangan (make a match), dikembangkan tidak hanya untuk penelitian mata pelajaran matematika namun 
untuk semua mata pelajaran, sehingga dapat meningkatkan kualitas pembelajaran baik proses pembelajarannya maupun hasil belajar siswa.

2. Bagi guru matematika, model pembelajaran Kooperatif Tipe Make A Match dapat menjadi salah satu alternatif dalam pelaksanaan kegiatan pembelajaran.

3. Bagi guru matematika, agar model pembelajaran kooperatif tipe Make A Match sering diterapkan guru di kelas, karena model ini memberikan nilai kesetiakawanan, nilai kerjasama, tanggung jawab yang sangat bermanfaat ketika siswa berinteraksi dengan masyarakat.

4. Kepada siswa, khususnya kelas VI SD Negeri 168432 Kota Tebing Tinggi agar lebih giat lagi belajar matematika khususnya dalam memecahkan berbagai permasalahan dalam soal.

5. Dengan adanya penelitian ini, diharapakan kepada peneliti lain agar dapat memperhatikan kelemahan-kelemahan dalam penelitian ini sehingga ke depannya diharapkan diperoleh hasil yang lebih baik lagi.

\section{DAFTAR RUJUKAN}

Abdurrahman, Muliyono. 2009. Pendidikan Bagi Anak Berkesulitan Belajar. Jakarta: Rineka Cipta
Agus, Nuniek Avianti. 2007. Mudah Belajar Matematika 2: Untuk kelasVIII Sekolah Menengah Pertamal Madrasyah Tsanawiyah. Jakarta: Pusat perbukuan departemen pendidikan nasional.

Arikunto, Suharsimin. 2009. Penelitian Tindakan Kelas, Jakarta : Bumi Aksara.

Dimyanti dan Mudjiono. 2009. Belajar dan Pembelajaran. Jakarta: Rineka Cipta.

Hudojo, Herman. 2005. Pengembangan Kurikulum Dan Pembelajaran Matematika, Malang : Ikip Malang.

Isjoni. 2009. Pembelajaran kooperatif. Yogyakarta: Pustaka Pelajar.

Istarani. 2011. 58 Model Pembelajran Inovatif. Medan: Media Persada.

Kunandar. 2007. Guru Profesional. Jakarta : Raja Grafindo Persada.

Kunandar. 2010. Langkah Mudah Penelitian Tindakan Kelas Sebagai Pengembangan Profesi guru. Jakarta: Raja Grafindo Persada.

Muslich, $\quad 2009$. Melaksanakan Penelitian Tindakan Kelas Itu Mudah. Jakarta: Bumi aksara.

Rohani, Ahmad. 2004. Pengolalan Pembelajaran Edisi Refisi. Jakarta: Rineka Cipta 
Nurainun Harahap : Effort To Increase Activity ..

Sinaga, B, dkk. 2013. Matematika SMP /MTS Kelas VII Kurikulum 2013. Jakarta: Politeknik Negeri Media Kreatif.

Slameto. 2010. Belajar Dan FaktorFaktor Yang

Mempengaruhinya. Jakarta: Rineka Cipta

Suprijono, Agus. 2009. Cooperative Learning Teori Dan Aplikasi PAIKEM. Yogyakarta: Pustaka Pelajar.

Trianto. 2009. Mendesain Model Pembelajaran Inovatif Kontenporer. Jakarta: Bumi Aksara. 